\title{
Moravecnema segonzaci gen. et sp. n. (Nematoda: Cystidicolidae) from Pachycara thermophilum (Zoarcidae), a deep-sea hydrothermal vent fish from the Mid-Atlantic Ridge
}

\author{
Jean-Lou Justine, Jimmy Cassone and Annie Petter \\ Laboratoire de Biologie Parasitaire, Protistologie, Helminthologie, Muséum National d'Histoire Naturelle, 61 Rue Buffon, \\ 75231 Paris cedex 05, France
}

Key words: Nematoda, Cystidicolidae, deep-sea fish, Moravecnema segonzaci

\begin{abstract}
A new cystidicolid nematode, Moravecnema segonzaci gen. et sp. $\mathrm{n}$. is described from the intestine of the teleost fish Pachycara thermophilum Geistdoerfer (Zoarcidae) from the hydrothermal sites Logatchev and Snake Pit-Moose of the MidAtlantic Ridge, at depths of 3,008; 3,492, and 3,510 m. The new genus Moravecnema is characterised by a dorsoventrally elongated oral opening, rudimentary pseudolabia, and four pairs of precloacal and six pairs of postcloacal caudal papillae in the male. The species has two spicules of unequal length, about 330 and $80 \mu \mathrm{m}$ long. Males are about $5 \mathrm{~mm}$ and females about 5-10 $\mathrm{mm}$ long. Eggs have long thin polar filaments. This is the first species of parasitic nematode described from a fish endemic to hydrothermal deep-sea vents.
\end{abstract}

Biological communities living in venting areas occurring along oceanic ridges are composed of numerous endemic species adapted to extreme environment (Van Dover et al. 2002). Nevertheless, very little is known about parasitism in these communities. We describe here what is probably the first parasitic nematode from a fish endemic to hydrothermal vents.

\section{MATERIALS AND METHODS}

The fish were caught by slurp gun by the submarine Alvin during the American Cruise DIVERSExpedition, on two hydrothermal vents of Mid-Atlantic Ridge, namely Logatchev and Snake Pit-Moose, at depths of 3,008; 3,492, and 3,510 m. Fish were determined by Filipe Porteiro (University of the Azores, Portugal) and dissected for parasites by Michel Segonzac on board; nematodes were found only in the intestine, and were fixed in formalin. One nematode was collected from a fish in the site Logatchev; others were collected from fish from the site Snake Pit-Moose. Specimens were cleared in lactophenol and drawings were made with an Olympus BH-2 microscope equipped with Nomarski interference contrast optics. All measurements are in $\mu \mathrm{m}$ unless otherwise stated.

\section{DESCRIPTION}

\section{Moravecnema gen. n.}

Diagnosis. Habronematoidea, Cystidicolidae. Body filiform. Oral opening dorsoventrally elongated, hexagonal in shape. Pseudolabia rudimentary, with rounded free margins scarcely protruding in oral opening. Four submedian buccal processes on margin of oral opening. Four submedian papillae and 2 lateral amphids. Buccal cavity long, dilated dorsoventrally at anterior extremity. Oesophagus divided into short anterior muscular and long posterior glandular parts. Male: Caudal alae present. Area rugosa absent. Spicules unequal. Four pairs of precloacal papillae arranged in two groups and 6 pairs postcloacal. Female amphidelphic. Vulva located at two thirds of total length. Mature eggs with filaments. Type and only species: Moravecnema segonzaci $\mathrm{sp} . \mathrm{n}$.

E $\mathrm{t} \mathrm{y} \mathrm{m} \mathrm{o} 1 \mathrm{og}$ y : The genus is dedicated to Professor František Moravec, in recognition to his outstanding work on systematics of fish nematodes. Gender neuter.

\section{Moravecnema segonzaci $\mathrm{sp} . \mathrm{n}$.}

Figs. 1, 2

Description. Body filiform. Cuticle with fine transverse striations. Oral opening dorsoventrally elongated, hexagonal in shape, with lateral sides longer than submedian ones. Two lateral rudimentary pseudolabia with rounded free margins scarcely protruding in oral opening and lacking anterior conical protuberances. Four submedian buccal processes present on margin of oral aperture. Four submedian cephalic papillae and 2 lateral amphids. Buccal cavity long, narrow, dilated dorsoventrally at its anterior end to form prostom. Oesophagus divided into muscular and glandular parts, muscular part very short. Deirids tiny, spine-like, located just anterior to posterior end of buccal cavity. Nerve ring and excretory pore located at anterior and posterior thirds, respectively, of muscular oesophagus. Tail rounded in both sexes.

MALE (measurements given for holotype, with those of two paratypes $45 \mathrm{JL}$ in parenthesis): Body length $5,800(5,000,5,000)$, maximum width $62(62,60)$. Posterior part of body ventrally coiled. Length of buccal cavity $130(130,135)$. Anterior muscular part of 


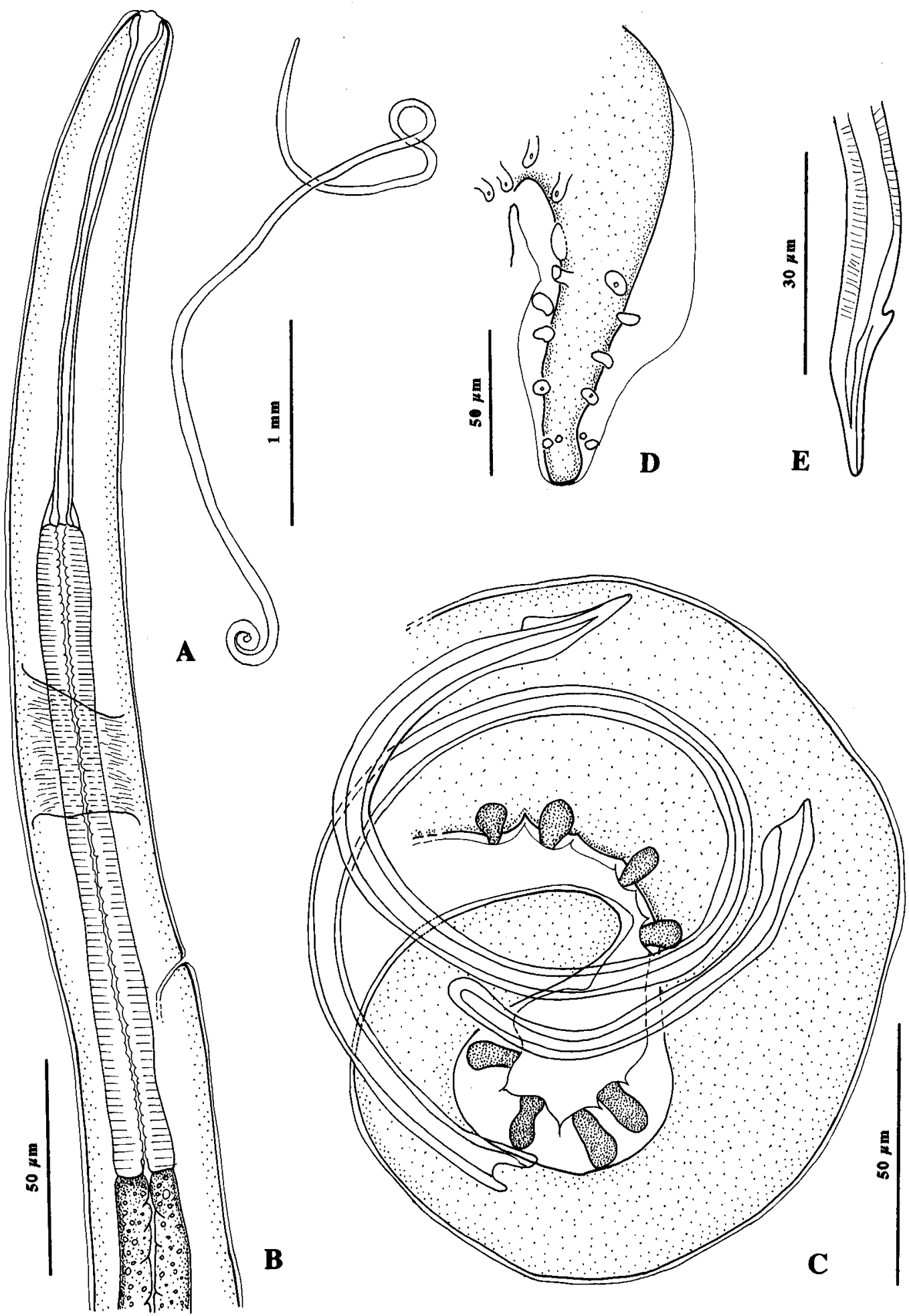

Fig. 1. Moravecnema segonzaci sp. n., male. Holotype, except D, paratype 45JL. A - general body shape; B - anterior end, lateral view; $\mathbf{C}$ - posterior end, lateral view; D - posterior end, ventral view (protruding spicules not drawn); $\mathbf{E}-$ distal end of long spicule. 


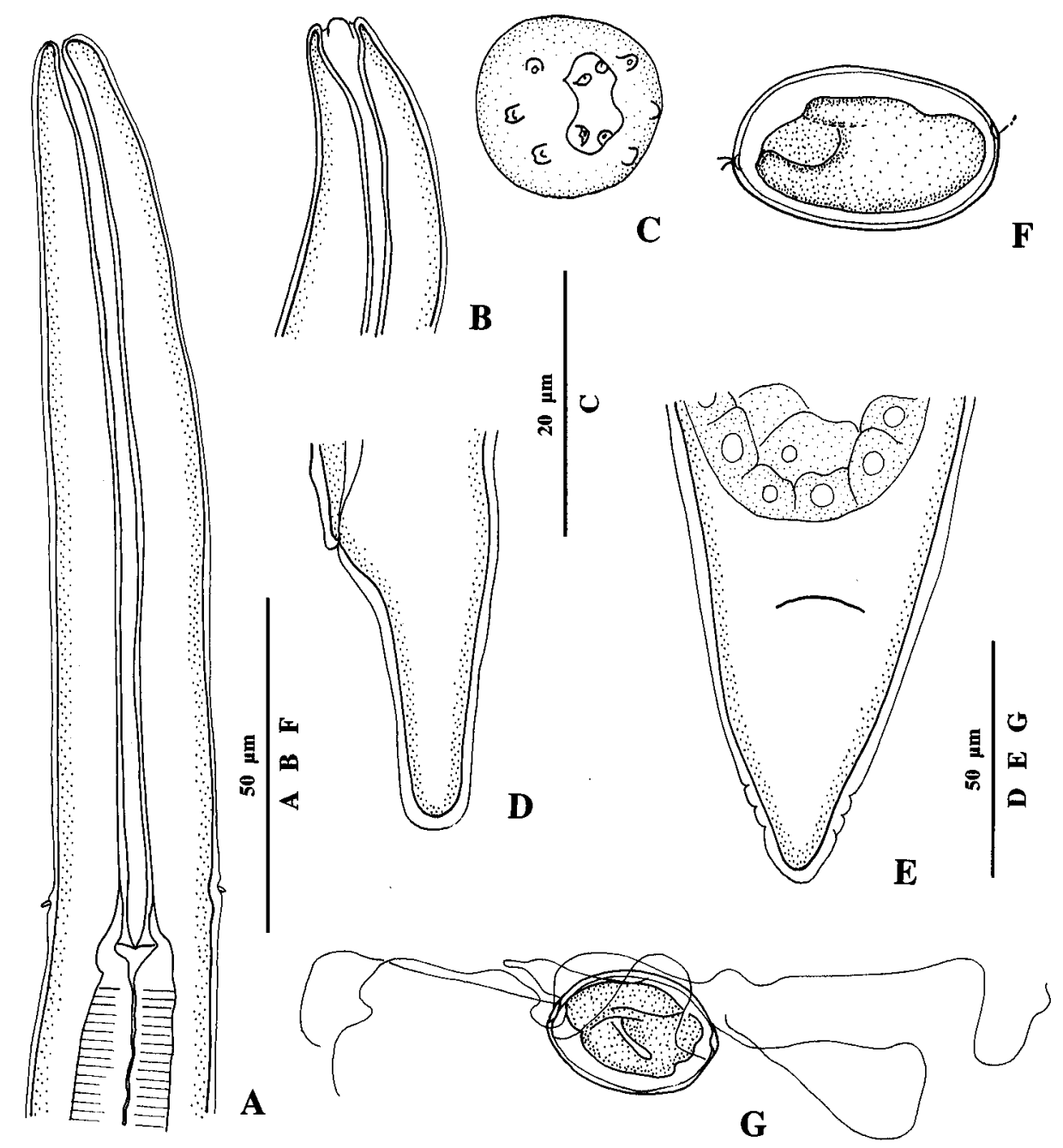

Fig. 2. Moravecnema segonzaci sp. n., female, paratypes. A - 46JL, anterior end, dorsal view; $\mathbf{B}-45 \mathrm{JL}$, anterior end, lateral view; $\mathbf{C}-45 \mathrm{JL}$, head, en face view; D - 46JL, tail, lateral view; $\mathbf{E}$ - allotype, tail, ventral view; $\mathbf{F}$ - allotype, egg in uterus; $\mathbf{G}$ 45JL, egg freed from uterus, with visible filaments.

oesophagus $160(160,155)$ long, posterior glandular part $690(870,910)$ long, total length $850(1,030$, 1,065). Excretory pore and middle of nerve ring (260) and 180, respectively, from cephalic apex. Cloacal opening 150 (150) from posterior extremity. Caudal alae present. Area rugosa absent. Four pairs of precloacal pedunculate papillae arranged in two groups, 6 pairs of postcloacal pedunculate papillae; papillae of 5th and 6th pairs small, located near caudal end, 5th pair ventral to 6th pair. Phasmids not found. Short spicule arcuate, rounded at distal extremity, $100(80$, 87 ) long, proximal extremity 10 wide. Long spicule 360 $(330,260)$ long, proximal extremity 10 wide, distal extremity pointed with a cuticular spur at 23 from end. Gubernaculum absent.

FEMALE (measurements given for one paratype $45 \mathrm{JL}$, with those of other paratypes $45 \mathrm{JL}$ and paratypes 48JL in parenthesis): Body length 4,650 (-, 9,800$10,250)$, maximum width $110(100,100)$. Length of buccal cavity 125 (100-140, 105-125). Anterior muscular part of oesophagus 190 (135-190, 170-185) long, posterior glandular part 1,200 (735, 705-1,820) long, total length 1,375 (870, 875-1,400). Excretory pore 207 from cephalic apex. Amphidelphic. Vulva at about 2 thirds from cephalic apex $(-, 6,500-7,100)$. Eggs larvated in vagina, 37-42 / 25 with 1-5 thin filaments, 40-140 long, arising from a small plug at each pole. Tail $60(65,95)$ long.

T y p e h o s t: Pachycara thermophilum Geistdoerfer, 1994 (Zoarcidae).

$\mathrm{T}$ y p e 1 o c a 1 i t i e s : Hydrothermal vent Logatchev, $14^{\circ} 45^{\prime} 19^{\prime} \mathrm{N}, 44^{\circ} 58^{\prime} 76^{\prime} \mathrm{W}$, depth $3,008 \mathrm{~m}$, and hydrothermal vent Snake Pit-Moose, $23^{\circ} 22^{\prime} 90^{\prime \prime} \mathrm{N}, 44^{\circ} 55^{\prime} 80^{\prime} \mathrm{W}$, depth 3,492 and $3,510 \mathrm{~m}$.

S p e c i m e n s d e p o s i t e d: Muséum National d'Histoire Naturelle, Paris: holotype, 44JL, one complete male, fish number 3667,7 July 2001 , Site Logatchev, $14^{\circ} 45^{\prime} 19^{\prime \prime}$, 445' $76^{\prime \prime} \mathrm{W}, 3,008 \mathrm{~m}$; paratypes: 45JL (one complete 
female (allotype), one complete male, several fragments of females), fish number 3674, 16 July 2001, Site Snake Pit-

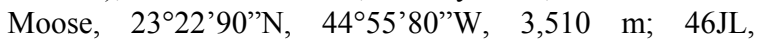
fragments of females, same fish; 48JL, three complete females, fish number 3672, Site Snake Pit-Moose, 14 July 2001, 3,492 m. Institute of Parasitology, Academy of Sciences of the Czech Republic, České Budějovice, Czech Republic, Coll. No. N-796: one male paratype from fish number 3674.

I n f e c t i o n : Site Logatchev, 06/07/2001, 2 fish specimens dissected, 1 (fish 3667) with 1 male nematode (44JL). Site Snake Pit-Moose, 14/07/2001 and 16/07/2001, 5 fish specimens dissected, 1 (fish 3672) with 3 female nematodes (48JL), 1 (fish 3674) with several male and female nematodes (45JL, 46JL).

E $\mathrm{t} y \mathrm{~m}$ o 1 o $\mathrm{g} \mathrm{y}$ : The species is dedicated to Michel Segonzac, who collected the specimens.

\section{DISCUSSION}

This species, by its slender form, its very long buccal cavity, and the anterior extremity devoid of lateral apical protuberances, is reminiscent of certain Rhabdochoni-dae, especially the genus Johnstonmawsonia Campana-Rouget, 1955. However, by its dorsoventrally elongated oral aperture and prostom, the presence of pseudolabia, and the aspect of the posterior male extremity with caudal alae and four pairs of precloacal pedunculate papillae grouped by pairs, the species belongs to the Cystidicolidae.

Chabaud (1975) recognised 12 genera in the Cystidicolidae. Since this review, 4 new genera have been described: Neoascarophis Machida, 1976, Caballeronema Margolis, 1977, Prospinitectus Petter, 1979, and Pseudascarophis Ko, Margolis et Machida, 1985 (Ko et al. 1985, Machida 1976, Margolis 1977, Petter 1979). Three genera have been revalidated: Capillospirura Skrjabin, 1924 by Appy and Anderson (1982), Comephoronema Layman, 1933 by Moravec and Nagasawa (1999), and Sterliadochona by Maggenti and Paxman (1971) (see also Petter 1984), and Johnstonmawsonoides Machida, 1975, originally described in the Rhabdochonidae by Machida (1975), has been trans-ferred to the Cystidicolidae by Moravec et al. (2001). The Cystidicolidae now include twenty genera, which are mainly distinguished by their cephalic structures.

The new genus Moravecnema is characterised by its reduced, rounded pseudolabia, which separates it from all other genera in this family. The closest genus is Johnstonmawsonoides Machida, 1975. Johnstonmawsonoides differs from Moravecnema in having the buccal aperture oval instead of hexagonal, and in the total absence of pseudolabia and the presence of an area rugosa in the male.

The host fish, the zoarcid eelpout Pachycara thermophilum, is an endemic species associated with hydrothermal vents of the Mid-Atlantic Ridge (Geistdoerfer 1994). The fish is present in all hydrothermal sites investigated, and is particularly abundant in the site Snake Pit (named after the fish), with 5-10 individuals per square meter in certain places, including the bottom of active chimneys (Segonzac 1992). The accompanying fauna is composed of decapod crustaceans (caridid shrimps, crabs) and molluscs (gastropods and bivalves); small populations of amphipods and copepods are also present. In the site Logatchev, the fish is rare, the accompanying fauna is similar and also includes dense ophiurid populations. Cystidicolid nematodes from marine fish generally use amphipod and decapod crustaceans as intermediate hosts (Anderson 2000); it is likely that locally present crustaceans play a role in the life cycle of Moravecnema segonzaci.

Parasites of deep-sea fishes have been studied for decades, but it is generally thought that our knowledge is still fragmentary (Campbell 1983). The abundant life associated with hydrothermal vents has been discovered only after 1977 and constitutes a very special part of the deep-sea fauna. Although more than 400 new species have been described from hydrothermal vents (Van Dover et al. 2002), the number of known species of parasites is still low. Parasites of invertebrates described so far include copepod parasites of cephalopods (Humes and Voight 1997, Lopez-Gonzalez et al. 2000) or of copepods (Huys and Conroy-Dalton 1997). A single species of helminth parasite of hydrothermal fish has been described before: the acanthocephalan Hypoechinorhynchus thermaceri Buron, 1988, from the zoarcid Thermarces andersoni Rosenblatt et Cohen, 1986 in the East Pacific Rise. No parasitic nematodes have been mentioned from this fish (Buron 1988). In addition to Moravecnema segonzaci described here, certain specimens of $P$. thermophilum contained undetermined intestinal trematodes, but no acanthocephalans (Segonzac and Buron, pers. comm.).

Among the numerous cystidicolid nematodes described, several are parasitic in fish caught at relatively deep depth, including several zoarcids, but none from hydrothermal vents. Moravecnema segonzaci is thus the first parasitic nematode described from a hydrothermal vent fish. It is likely that the species evolved from other cystidicolid nematodes parasitic in non-hydrothermal deep-sea fishes.

Acknowledgements. We sincerely thank Cindy Van Dover (College of William \& Mary, Williamsburg, USA), chief scientist of the DIVERSExpedition Cruise, who made the nematodes available to us, Michel Segonzac (Ifremer, Brest, France), who collected the parasites, and Isaure de Buron (College of Charleston, USA), who forwarded the specimens and commented upon the acanthocephalans and other parasites of hydrothermal vent fish. These three scientists also made useful comments on the manuscript. Roselyne Tcheprakoff, although recently retired, kindly inked the drawings. 


\section{REFERENCES}

ANDERSON R.C. 2000: Nematode Parasites of Vertebrates. Their Development and Transmission. 2nd Ed. CABI Publishing, Wallingford, Oxon \& New York, 650 pp.

APPY R.G., ANDERSON R.C. 1982: The genus Capillospirura Skrjabin, 1924 (Nematoda: Cystidicolidae) of sturgeons. Can. J. Zool. 60: 194-202.

BURON I., de 1988: Hypoechinorhynchus thermaceri n. sp. (Acanthocephala: Hypoechinorhynchidae) from the deepsea zoarcid fish Thermaceres [sic] andersoni Rosenblatt and Cohen, 1986. J. Parasitol. 74: 339-342.

CAMPBELL R.A. 1983: Parasitism in the deep sea. In: G.T. Rowe (Ed.), The Sea, Vol. 8. Deep-Sea Biology. WileyInterscience, New York, pp. 473-552.

CHABAUD A.G. 1975: Keys to genera of the order Spirurida. Part 2. Spiruroidea, Habronematoidea and Acuarioidea. In: R.C. Anderson, A.G. Chabaud and S. Willmott (Eds.), CIH Keys to the Nematode Parasites of Vertebrates, No. 3. Commonwealth Agricultural Bureaux, Farnham Royal, pp. 29-58.

GEISTDOERFER P. 1994: Pachycara thermophilum, une nouvelle espèce de poisson Zoarcidae des sites hydrothermaux de la dorsale médio-atlantique. Cybium 18: 109115.

HUMES A.G., VOIGHT J.R. 1997: Cholidya polypi (Copepoda: Harpacticoida: Tisbidae), a parasite of deepsea octopuses in the north Atlantic and northeastern Pacific. Ophelia 46: 65-81.

HUYS R., CONROY-DALTON S. 1997: Discovery of hydrothermal vent Tantulocarida on a new genus of Argestidae (Copepoda: Harpacticoida). Cah. Biol. Mar. 38: 235-249.

KO R.C., MARGOLIS L., MACHIDA M. 1985: Pseudascarophis kyphosi n. gen., n. sp. (Nematoda: Cystidicolidae) from the stomach of the fish Kyphosus cinerascens (Forskål) [sic] from Japan. Can. J. Zool. 63: 2684-2688.

LOPEZ-GONZALEZ P.J., BRESCIANI J., HUYS R., GONZALEZ A.F., GUERRA A., PASCUAL S. 2000: Description of Genesis vulcanoctopusi gen. et sp. nov. (Copepoda: Tisbidae) parasitic on a hydrothermal vent octopod and a reinterpretation of the life cycle of cholidyinid harpacticoids. Cah. Biol. Mar. 41: 241-253.

MACHIDA M. 1975: Nematodes from the deep-sea fishes of Suruga Bay. I. A new rhabdochonid, Johnstonmawson-

Received 8 May 2002 oides nemichthyos from the nemichthyid fish. Bull. Nat. Sci. Mus., Tokyo. Ser. A (Zool.) 1: 1-4.

MACHIDA M. 1976: Nematodes from the deep-sea fishes of Suruga Bay. II. Two new rhabdochonid nematodes from the macrourid fishes. Bull. Nat. Sci. Mus., Tokyo, Ser. A (Zool.) 2: 1-6.

MAGGENTI A.R., PAXMAN G.A. 1971: Sterliadochona pedispicula n. sp. (Nematoda: Spirurinae) from Salmo gairdnerii Richardson, and a discussion of the genera Sterliadochona Skrjabin, 1946 and Cystidicoloides Skinker, 1931. Proc. Helminthol. Soc. Wash. 38: 210-214.

MARGOLIS L. 1977: Caballeronema gen. nov. for Metabronema wardlei Smedley, 1934 (Nematoda, Spiruroidea) from the marine fish Scorpaenichthys marmoratus from the Pacific coast of Canada. Excerta Parasitólogica en Memoria del Doctor Eduardo Caballero y Caballero. Universidad Nacional Autónoma de México, Instituto de Biología, Publicaciones Especiales 4: 447454.

MORAVEC F., NAGASAWA K. 1999: Morphology and taxonomy of Salvelinema species (Nematoda: Cystidicolidae), swimbladder parasites of Pacific area salmonids. Folia Parasitol. 46: 123-131.

MORAVEC F., SALGADO-MALDONADO G., CABANASCARRANZA G. 2001: New observations on Vasorhabdochona cablei (Nematoda: Rhabdochonidae) with remarks to the family Rhabdochonidae. Helminthologia 38: 231235.

PETTER A.J. 1979: Trois Nématodes parasites de Poissons en Malaisie. Bull. Mus. Natl. Hist. Nat., Paris, $4^{\circ}$ sér 1: 585596.

PETTER A.J. 1984: Nématodes de poissons du Paraguay 2. Habronematoidea (Spirurida). Description de 4 espèces nouvelles de la famille des Cystidicolidae. Rev. Suisse Zool. 91: 935-952.

SEGONZAC M. 1992: Les peuplements associés à l'hydrothermalisme océanique du Snake Pit (dorsale médioatlantique; $23^{\circ} \mathrm{N}, 3480 \mathrm{~m}$ ): composition et microdistribution de la mégafaune. C. R. Acad. Sci. Sér. III Sc. Vie 314: 593-600.

VAN DOVER C.L., GERMAN C.R., SPEER K.G., PARSON L.M., VRIJENHOEK R.C. 2002: Evolution and biogeography of deep-sea vent and seep invertebrates. Science 295: 1253-1257.

Accepted 13 June 2002 